\title{
Estimation of soil erosion using RUSLE and GIS techniques: a case study of Barakar River basin, Jharkhand, India
}

\author{
Sumantra Sarathi Biswas ${ }^{1} \cdot$ Padmini Pani $^{1}$
}

Received: 23 August 2015/Accepted: 13 October 2015/Published online: 20 November 2015

(C) Springer International Publishing Switzerland 2015

\begin{abstract}
An integrated method has been adopted to estimate soil loss in a plateau and plateau fringe river basin where soil erosion is significant. The integration of Revised Universal Soil Loss Equation model and geographical Information technology has been used for soil loss estimation. In GIS platform, the overlay of rainfall-runoff erosivity factor, soil erodibility factor, slope length factor, slope steepness factor, cover and management factor, support and conservation practices factor results that the high amount of soil loss (more than $100 \mathrm{t} \mathrm{ha}^{-1}$ year $^{-1}$ ) is significantly low and occupies $0.08 \%$ of the entire study area. High soil loss in upstream of the basin has a close relation to LS and $\mathrm{K}$ factor and drainage density. As a result of soil loss in the upper catchment areas, reservoir capacity has been depleted both in dead and live storage space. It is concluded that soil erosion has a significant impact on plateau fringe areas and the estimation of soil loss is an essential input for the adoption of proper land use planning and development strategies.
\end{abstract}

Keywords RUSLE - Soil erosion · GIS · Plateau and Plateau fringe $\cdot$ Reservoir sedimentation

\section{Introduction}

Soil erosion occurs as a result of changes in agricultural practices, agricultural intensification, land degradation and global climate change (Yang et al. 2003). Inter-rill and

Sumantra Sarathi Biswas

sumantra.geo5@gmail.com

1 Centre for the Study of Regional Development, Jawaharlal Nehru University, New Delhi 110067, India gully erosion are the results of the removal of soil particle from its parent place of origin by the raindrops. These detached particles of soil are then transported ultimately to the river basin that enrich the suspended sediment yield, bed load and sediment delivery ratio of the river basin (Beskow et al. 2009). The amount of soil erosion and sediment yield is measured quantitatively and consistently with the help of two types of models: physical based models and empirical models. The physical based models illustrate the mechanism of the controlling of the erosion processes by solving corresponding various equations, while the empirical models are widely used for measurement of the surface soil loss and sediment yield from the catchment areas (for sediment yield estimation) (Bhattarai and Dutta 2007). Soil erosion is the major problem for a river basin as it removes nutrient that is essential for the growth of the plants and increases sedimentation of the river channel and reservoirs (Narayan and Babu 1983). It has been estimated by Narayan and Babu (1983) that in India, $16.4 \mathrm{t} \mathrm{ha}^{-1}$ (5334 m-tonnes) of soil detaches annually due to various reasons, $29 \%$ of soil loss is carried away by the river into the sea and $10 \%$ into the reservoirs that lead to reservoir sedimentation. Soil is detached mainly by rainwater erosion (56\%) and wind erosion (28\%) (Brady and Weil 2012). However, physical deterioration (12\%) and chemical deterioration (4\%) also leads to soil erosion, even though in small amounts (Brady and Weil 2012). The decrease of soil erosion is associated with the increase in infiltration rate. After the infiltration process, the overflow surface water forms runoff. On the surface, the quantity of materials of different sizes increases with the increase in the velocity of the runoff. It is distinct in the upstream section of a river, where the slope is high. On the contrary, in the downstream section, the velocity decreases with the reduction in the slope that further encourages the sediment 
to deposit in the valley and the reservoir. Thus, the initiation of sediment deposition occurs as a result of soil loss in the catchment area (Jain 1996-1997). Several models such as EUROSEM (Morgan et al. 1998), LISEM (De Roo et al. 1996), SWAT (Arnold and Fohrer 2005), WEPP (Flanagan et al. 2007) have been developed to estimate soil erosion on basin scale.

Numerous scholars have worked on the soil erosion using different types of models based on the suitability of the regions across the world. Most of these works apply to the mountainous and plateau areas. The soil erosion models are too diversified globally. Millward and Mersey (1999) have worked on the Revised Universal Soil Loss Equation (RUSLE) model of soil erosion using IDRISI software in the mountainous area. A similar model was used by Rahman et al. (2009) in which they assessed soil erosion hazard using Z-score analysis with selected standardized factor and weight to compute a synthetic Soil Erosion Hazard Index (SEHI). Lim et al. (2005) has used the RUSLE model, in which they have developed a GIS-based Sediment Assessment Tool for Effective Erosion Control (SATEEC) to estimate soil erosion and sediment yield within a watershed. Meusburger et al. (2010) have modelled the soil erosion with USLE and Pan-European Soil Erosion Risk Assessment (PESERA) using IKONOS and Quick Bird images for derivation and detection of vegetation parameters in alpine catchment areas and found that the USLE model is less suitable than the PESERA-VBA model possibly due to the high impact of $\mathrm{c}$ factor. They have also found that the estimation of soil loss is greater in the USLE model than the PESERA model.

In context to the Indian perspective, some literature is available based on the hills and plateau regions. A comparison of DEM data having different resolutions has been done by Bhattarai and Dutta (2007), along with the use of GIS techniques to estimate soil erosion and sediment yield using USLE model and Sediment Delivery Ratio (SDR). It is observed that the generated yield is closer to the $30 \mathrm{~m}$ resolution than the $90 \mathrm{~m}$ resolution of the DEM data. In a study in the high altitudes, Jain et al. (2001) have estimated soil erosion for the Himalayan watershed using two models viz. Morgan Model (Morgan et al. 1984) that estimate the volume of overland flow and USLE model for estimation of soil erosion. They have found that the Morgan model is mostly suitable for hilly terrain like Himalaya, as the USLE model has a greater value of soil erosion. In a study in plateau areas, Jain and Kothyari (2000) have estimated soil erosion and sediment yield through USLE model and SDR using GIS techniques for the two watersheds of Jharkhand. They found the sediment source areas using soil maps and sediment delivery ratio. Another study in the same areas, has been done by Pandey et al. (2007), in which they have identified the critical erosion prone areas using USLE model through GIS and remote sensing techniques and found that the differences between the observed and the estimated soil loss. A study by Ghosh and Guchhait (2012), have estimated soil loss using USLE and Morgan, Morgan and Finney (MMF) methods in the lateritic tracts of Jharkhand and found that the estimated soil loss is greater in the MMF method than in the USLE method in most of the soil types. Soil loss estimation has also been done in the southern regions of India by Prasannakumar et al. (2012). In this study, they have generated cover-management factor (C) using Normalized Difference Vegetation Index (NDVI), an indicator of vegetation health to estimate soil erosion. Most of the works have been carried out in the hills and plateau regions of India, as this areas have faced more soil loss than the plain regions.

Soil erosion is one of the key land degradation problems in the plateau area river basins of eastern India. Soil erosion and various other degradation processes enhance sedimentation process of the rivers of the plateau area of Jharkhand. The Barakar River Basin is a major catchment area of Chotanagpur Plateau in Jharkhand. The present study is an attempt to focus on the estimation of soil erosion in the Barakar River Basin and its impact on the Maithon Dam reservoir sedimentation.

\section{Location and description of the study area}

The Barakar River is the principal tributary of the Damodar River in eastern India. It originates at the Hazaribagh Plateau near Padma in Hazaribagh district of Jharkhand and flows for $225 \mathrm{~km}$ across the northern part of the Chotanagpur Plateau, mostly in a west to east direction, before joining the Damodar River at Dishergarh in Bardhhaman district of West Bengal (Fig. 1). The catchment area of the Barakar River is $6159 \mathrm{~km}^{2}$. The river basin, a part of the Chotanagpur Plateau, is characterised by very complex structural geology. The river flows through the plateau and plateau fringe area where soil loss is significant. The soil in the Barakar river basin is mainly red soil and red loamy soil of the Chotanagpur gneiss and granitic surface (Singh 1971; ICAR 2008). Loose sandy soil and lateritic soil have also developed over the Gondwana sediment and pats respectively (Sen and Prasad 2002; ICAR 2008). Due to the high presence of ferruginous biotite and hornblende, the soils over the gneiss and granite surface are red and reddish black in colour (Singh 1971). The elevation varies from 150 to $400 \mathrm{~m}$ above the mean sea level in the study area. The general slope of the basin is toward the east and south-eastward direction. The basin is characterised by 


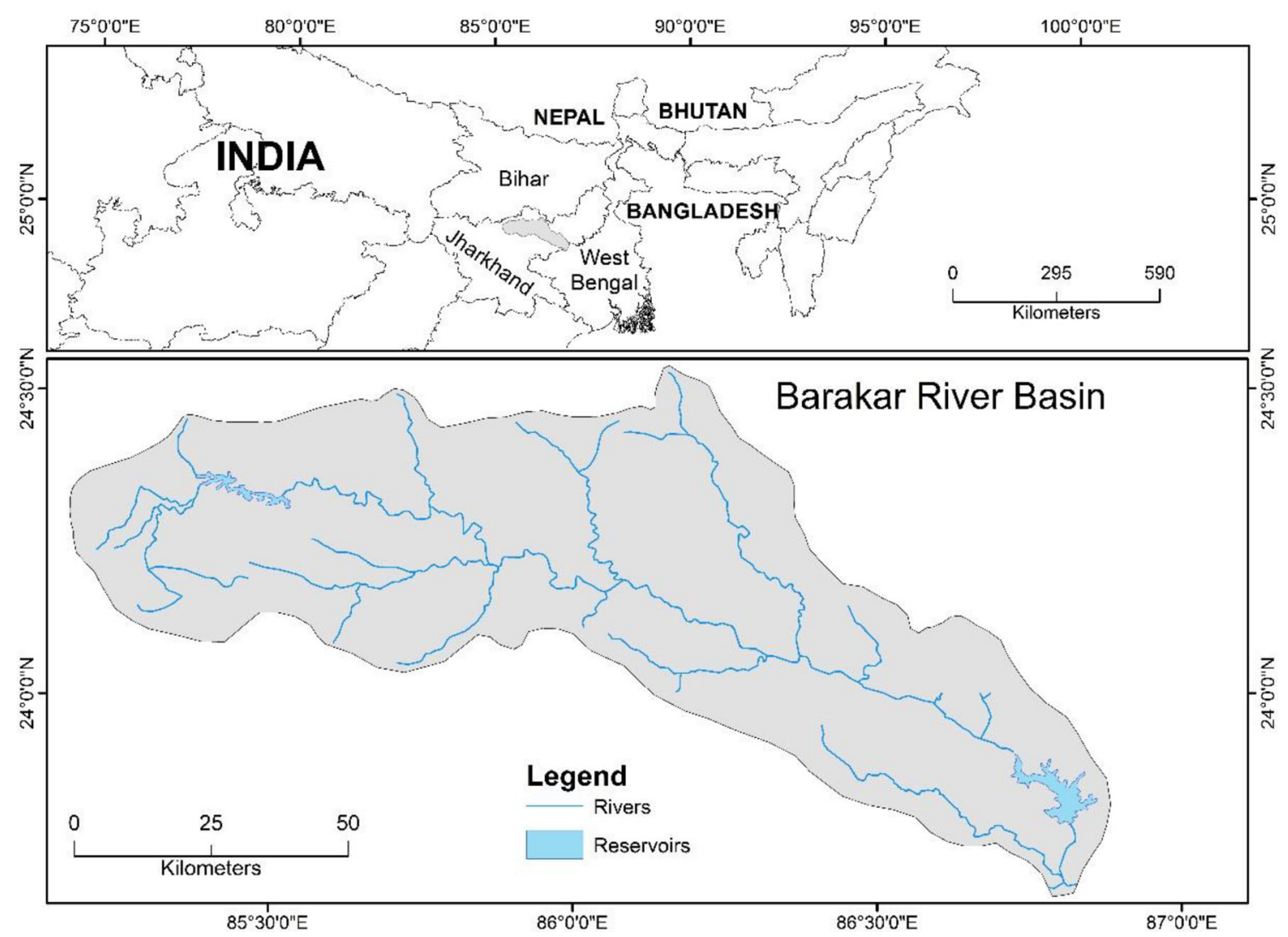

Fig. 1 Location map of the Barakar River Basin

dry winter from November to February and wet summer from March to May. Maximum occurrences of rainfall take place from July to September, which accounts for more than $90 \%$ of the total rainfall in the state. The other months of the year April, May and October experience a little amount of rainfall. The vegetation is scattered throughout the basin, and the forest covers have been found in the plateau areas of Paresnath Hills and Hazaribagh Plateau. The upper section of the Damodar-Barakar river valley belongs to the plateau and plateau fringe area, and $66 \%$ of this region has faced the problem of land degradation due to soil erosion and other types of erosion (Misra 1999). Though, the area, is covered with thick forest cover with the grasses, $35 \%$ of the agricultural land is prone to sheet erosion (Misra 1999). Even though, the dense forest and grasses have performed the function of protective soil cover, but of late, several factors are responsible for the soil detachment from the land surface and the transportation of sediment to the nearby streams. Mainly, the removal of soil cover or the vegetation, improper use of the land in agricultural activities and the increase of the concretization, masonry works, engineering constructions and other human activities accelerate the tempo of soil erosion from the land surface (Pandey et al. 2007).

\section{Materials and methods}

Soil erosion of a catchment area is estimated through several models. In this study, soil erosion has been estimated with the help of RUSLE model (Renard et al. 1991; Millward and Mersey 1999; Jiang et al. 2015). The RUSLE model has been used for its simplified nature and this model is the latest version of soil loss measurement in comparison to the USLE (Musgrave 1947; Wischmeier and Smith 1965) and the MUSLE models (Williams 1975). RUSLE has more flexibility in modelling erosion in new conditions and is more efficient than USLE (Wischmeier and Smith 1965). RUSLE is a combination of empirical and process-based design and has the advantage over USLE in terms of its optimum use of the database. RUSLE factors allow more flexibility in calculating soil loss by calculating them precisely into subfactors. It also allows to estimate deposition through sediment transport (Yoder et al. 2004). However, USLE/RUSLE cannot measure the real picture of soil erosion as the basis of this model is a coefficient that is calibrated on the basis of the observations. Nontheless, it is widely applicable for its simplicity and data availability (Jain and Kothyari 2000; Bhattarai and Duttta 2007; Pandey et al. 2007; Sinha and Joshi 2012; 
Jiang et al. 2015; Balasubramani et al. 2015). From the collected and calculated data, RUSLE can estimate the soil loss on the valley side of the basin area. With the help of the obtained result from RUSLE model, sedimentation of the river basin and the reservoirs can be assessed. Through the RUSLE model soil loss can be estimated for river basins as well as for individual farm fields or other areal units also.

\section{Generation of the thematic maps of RUSLE model}

The primary equation (Eq. 1) of RUSLE method for predicting annual soil loss is as:

$A=R \times K \times L \times S \times C \times P$

where, $\mathrm{A}$ is the average annual soil loss per unit area (tons/ $\left.\mathrm{ha}^{-1}\right) ; \mathrm{R}$ is the rainfall-runoff erosivity factor (MJ mm $\mathrm{ha}^{-1} \mathrm{~h}^{-1}$ ); $\mathrm{K}$ is the soil erodibility factor (ton ha $\mathrm{h} \mathrm{MJ}^{-1}$ $\left.\mathrm{mm}^{-1}\right)$; $\mathrm{L}$ is the slope length factor; $\mathrm{S}$ is the slope steepness factor; $\mathrm{C}$ is the cover and management factor; $\mathrm{P}$ is the support and conservation practices factor.

\section{Rainfall erosivity factor $(R)$}

The rainfall erosivity factor $(\mathrm{R})$ acts as the force for sheet and rill erosion without protection. The high rate of rainfall with large drop size can erode the soil particles faster than normal rainfall. High runoff flow is caused due to heavy storm leads to the majority of sheet or rill erosion. The rainfall data for calculation of rainfall erosivity has been collected from the Hydraulic Data Division, DVC, Maithon. It provides 13 years (1994-2006) of daily rainfall data of six rainfall gauging station of the Barakar River basin. For the generation of rainfall erosivity map of the study area, R-factor has been estimated by the equation developed by Renard and Freimund (1994). The equation is also used by Pandey et al. (2007) and Beskow et al. (2009). The average monthly erosivity $E l_{i}$ equation (Eq. 2) is as follows:

$E l_{i}=\frac{125.92 \times\left(\frac{r_{i}^{2}}{P}\right)^{0.603}+111.173 \times\left(\frac{r_{i}^{2}}{P}\right)^{0.691}+68.73 \times\left(\frac{r_{i}^{2}}{P}\right)^{0.841}}{3}$

where, $E l_{i}$ is the average monthly erosivity $\left(\mathrm{MJ} \mathrm{mm} \mathrm{ha}^{-1}\right.$ $\mathrm{h}^{-1}$ ) for the month of $i ; r$ is the average monthly rainfall (mm) for the month $i$ and $\mathrm{P}$ is the mean annual precipitation (mm). Using Eq. 2, monthly rainfall erosivity has been obtained. The annual rainfall erosivity has been derived by summing up of the monthly erosivity values of each of the stations (Table 1). The spatial distribution of $\mathrm{R}$ factor has been obtained using the Kriging method in ArcGIS (version 10) software.

\section{Soil erodibility $K$ factor}

Soil erodibility $(\mathrm{K})$ refers to the inherent susceptibility of the soil to erosion and it depends on the mineralogical, chemical, physical and morphological attributes of the soils (Pérez-Rodríguez et al. 2007). The $\mathrm{K}$ factor signifies the amount of soil loss per unit of erosive energy of rainfall, considering a plot of the clean bare soil of $9 \%$ slope and $22 \mathrm{~m}$ long (Brady and Weil 2012). The Soil erodibility factor is estimated using the soil type data. Collection of soil data and assigning the values of $\mathrm{K}$ factor from the field is too expensive and time-consuming. Thus, the soil data have been derived with the help of the district level maps provided by National Bureau of Soil Survey and Land Use Planning (ICAR) Regional Centre, Kolkata (1:50,000) (2008) and National Atlas and Thematic Mapping Organization (NATMO). The districts that are included in the Barakar River basin has been taken into consideration for the study. The soil erodibility factor map $(\mathrm{K})$ has been derived based on different soil types, texture and organic matter composition (percent of humus) of the soils. The types and texture of the soil have been classified according to the classification provided by United States Department of Agriculture (USDA). Soil types, texture and organic matter composition have been identified with the help of maps and information provided by National Bureau of Soil Survey and Land Use Planning (ICAR) Regional Centre, Kolkata (ICAR 2008). The corresponding values of $\mathrm{K}$ have been assigned based on different studies that have been carried out in India (Das 2012) and the maps provided by ICAR. Das (2012) has given a value of K based on several studies in India based on soil types, texture and organic matter, has been used in the study. 11 types of soil classes of the studied basin have been identified, and values are assigned to different classes of soil (Table 2).

\section{Topographic LS factor}

Topography plays a significant role in erosion or landslide. The topographic factor (LS) depicts the effects of topography on erosion and contains the length and steepness of the slope that influence the surface runoff speed (Beskow et al. 2009). The topographic factor includes the slope length factors (L) and slope steepness factors (S). The LS factor has been generated using the ASTER DEM (2011) (30 $\mathrm{m}$ resolution) that has been collected from USGS earth explorer. From the ASTER DEM image, the

of slope has been derived using ArcGIS (10). For the calculation of Slope length factor, the equation that has been given by McCool et al. (1987) has been used. If $\lambda$ is the horizontal projection of the slope length (in meter), then slope length factor ( $L$ factor) (Eq. 3) is given as: 
Table 1 Mean annual rainfallrunoff erosivity factor of six rainfall gauging station of the Barakar River Basin

\begin{tabular}{lll}
\hline Rainfall gauging station & Latitude and longitude & $\mathrm{R}\left(\mathrm{MJ} \mathrm{mm} \mathrm{ha} \mathrm{h}^{-1}\right)$ \\
\hline Barhi & $24^{\circ} 18^{\prime} 13^{\prime \prime} \mathrm{N}$ and $85^{\circ} 24^{\prime} 33^{\prime \prime} \mathrm{E}$ & 2854.578 \\
Tilaiya & $24^{\circ} 19^{\prime} 28^{\prime \prime} \mathrm{N}$ and $85^{\circ} 31^{\prime} 17^{\prime \prime} \mathrm{E}$ & 4284.992 \\
Barki Saria & $24^{\circ} 10^{\prime} 06^{\prime \prime} \mathrm{N}$ and $85^{\circ} 53^{\prime} 57^{\prime \prime} \mathrm{E}$ & 3978.065 \\
Palganj & $24^{\circ} 04^{\prime} 04^{\prime \prime} \mathrm{N}$ and $86^{\circ} 13^{\prime} 15^{\prime \prime} \mathrm{E}$ & 3599.735 \\
Nandadih & $23^{\circ} 59^{\prime} 27^{\prime \prime} \mathrm{N}$ and $86^{\circ} 33^{\prime} 00^{\prime \prime} \mathrm{E}$ & 4582.335 \\
Maithon & $23^{\circ} 47^{\prime} 06^{\prime \prime} \mathrm{N}$ and $86^{\circ} 48^{\prime} 43^{\prime \prime} \mathrm{E}$ & 4077.217 \\
\hline
\end{tabular}

Table $2 \mathrm{~K}$ factor value of soils of Barakar River basin

\begin{tabular}{lll}
\hline Soil textural class & Organic matter content $(\%)$ & K factor value \\
\hline Fine sandy loam & 2 & 0.72 \\
Very fine sandy loam & 2 & 0.92 \\
Silty clay & 2 & 0.51 \\
Silty clay loam & 2 & 0.72 \\
Sandy clay loam & 2 & 0.55 \\
Clay loam & 2 & 0.56 \\
Silt & 2 & 0.75 \\
Silt loam & 2 & 0.94 \\
Loamy sand & 2 & 0.22 \\
Sandy loam & 2 & 0.54 \\
Ultisol (loamy sand) & 0.5 & 0.27 \\
\hline
\end{tabular}

$L=\left(\frac{\lambda}{22.1}\right)^{m}$

where, $L$ is the slope length factor; $\lambda$ is the contributing slope length $(\mathrm{m}) ; m$ is the variable slope length exponent that varies based on slope steepness. The slope length exponent ' $m$ ' is related to the ratio of rill erosion to interrill erosion (caused by raindrop impact). The slope steepness has been considered that was provided by Pandey et al. (2007). The values of slope length exponent that has been considered as 0.3 for slopes less than $3 \%, 4$ for slope of $4 \%$ and 5 for slope that is greater than $5 \%$.

The slope steepness factor ( $S$ factor) is evaluated from the equations (Eqs. 4.1, 4.2) given by McCool et al. (1987) for slope longer than $4 \mathrm{~m}$ :

$S=10.8 \sin \theta+0.03$ when s $9 \%$

$S=16.8 \sin \theta-0.50$ when $s \geq 9 \%$

where, $S$ is the slope steepness factor (dimensionless) and $\theta$ is the slope angle (degree). The $\mathrm{L}$ and $\mathrm{S}$ factor layer has been generated by the multiplication of both $\mathrm{L}$ and $\mathrm{S}$ factor in raster calculator in Arc GIS.

\section{Crop management $(C)$ and support practice $(P)$ factor}

The $\mathrm{C}$ and $\mathrm{P}$ factors also play a significant role in the form of conservation practices. The cover management factor
(C) depends on the land use and it is the ratio of soil loss from a cropped land in a particular condition to the soil loss in the continuous tilled fallow on the same soil and slope (Pandey et al. 2007). The $\mathrm{C}$ and $\mathrm{P}$ factor values are assigned to different category based land use and land cover of the river basin. For the classification of land use and land cover, satellite image has been used, and it is provided by USGS Earth Explorer-Landsat 5 (2011) (spatial resolution $30 \mathrm{~m}$ ). From the satellite image, the basin area has been extracted and it is classified in six land use categories with supervised classification (Maximum Likelihood Classifier algorithm) using image processing software ERDAS IMAGINE (Joshi and Nagare 2009). Six land use/land cover categories have been identified viz. settlements/built up areas, waste land, agricultural land, reservoirs, rivers, and vegetation. The land use categories have been verified by ground truth verification during the field survey. The $\mathrm{C}$ factor map is associated with the land use and the land cover map of the basin. The land use which is associated with highly vulnerable to soil loss has been assigned as high value (highest value is 1) and vice versa. Table 3 shows the values of $\mathrm{C}$, and it has been assigned to the several studies in Jharkhand, India (Jain and Kothyari 2000; Pandey et al. 2007, 2008). The built up areas or settlements and its surrounding areas are associated with the high amount of soil loss and have been assigned as the value of 1. Similarly, agricultural practices and waste land/ barren land are associated with less soil erosion. Thus, these are assigned as 0.28 and 0.18 respectively. On the contrary, vegetation and forest protect the land from soil erosion thus it is assigned as low value (0.06) and reservoirs and rivers are not considered as soil erosion factors and these are designated as 0 .

The support practice factor $(\mathrm{P})$ is the ratio of soil loss with a particular support practices to the corresponding loss of up and down slope cultivation (Pandey et al. 2007; Brady and Weil 2012). The support practise factor (P) has been calculated based on the cultivation method. It is calculated as the relation between terracing and slope in the paddy field areas and is estimated according to the relation between contouring and slope in the crop field areas. Pandey et al. (2007), in their study on the small watershed of a basin of Jharkhand, has identified two classes of 
Table $3 \mathrm{C}$ factor values of different land use categories of the Barakar River Basin

\begin{tabular}{lll}
\hline Land use categories & C factor value & Source \\
\hline Agricultural lands & 0.28 & Pandey et al. (2007); Rao (1981) \\
Waste land & 0.18 & Pandey et al. (2007); Rao (1981) \\
Settlement/built-up areas & 1 & Pandey et al. (2007) \\
Reservoirs & 0 & Prasannakumar et al. (2012) \\
Rivers & 0 & Prasannakumar et al. (2012) \\
Vegetation covers & 0.006 & Pandey et al. (2007) \\
\hline
\end{tabular}

P-factor, viz. paddy and non-paddy areas. As the primary crop of the study area is paddy, support practises of the study area have been categorised into two types such as paddy fields and non-paddy fields and, the values have been assigned based on the previous study by Rao (1981), Pandey et al. (2007) and Balasubramani et al. (2015). Nonpaddy fields have been considered to be highly vulnerable to erosion and are designated a value 1 . The paddy areas have been designated as a value of 0.28 . The agricultural lands of paddy cultivation have been obtained from the classified images of Landsat 5 TM (2011) satellite images.

The soil erosion through the RUSLE model has been generated by multiplying all the required input thematic maps of the model in GIS platform. To run this model, five input raster files are needed as data files. These pre-required maps are namely the R factor, $\mathrm{K}$ factor, LS factor, $\mathrm{C}$-factor, $\mathrm{P}$ factor map of the area. The potential soil erosion and the actual soil erosion maps have been derived by multiplication of the thematic maps in raster calculation in ArcGIS using the R, K, LS factor maps and the R, K, LS, $\mathrm{C}, \mathrm{P}$ factor maps respectively.

Derived soil erosion map has been overlayed with the drainage density map of the basin to identify the effects of drainage density in soil erosion. The role of drainage density on soil loss has been established with multiplication of drainage density and soil loss map in raster calculator tool of ArcGIS. Drainage density (Dd) is a measure of total stream length of a basin to the total area of the basin (Strahler 1964). The drainage density has been calculated as defined by Horton (1945). The formula (Eq. 5) of drainage density $(D d)$ is as follow:

$D d=\frac{L_{u}}{A}$

where, $D d$ is the drainage density; $L_{u}$ is the total length of channels in a basin and $A$ represents the area of the basin.

\section{Analysis of effects of soil loss in reservoir sedimentation}

In order to analyse the role of soil loss in reservoir sedimentation, the temporal sedimentation rate of the Maithon Dam reservoir has been explained. Due to the unavailability of data on sediment discharge and sediment yield, the sediment delivery ratio has not been calculated and the sedimentation rate is used to put a highlight on reservoir and river sedimentation (Hardon 1993). The variation of the volume of sediment deposition from the mean deposition has been estimated with the help of sedimentation data of the Maithon reservoir and it is collected from the Hydraulic Data Division, DVC, Maithon. A graph has been plotted based on the distance from the dam towards the upstream of the reservoir in order to show the sedimentation rate of the different section of the reservoir. Spatial as well as the depthwise distribution of the sedimentation at the Maithon reservoir, has been analysed. The loss of various types of the storage capacity of the Maithon reservoir due to sedimentation has been interpreted with the help of the storage capacity data that has been collected from the Hydraulic Data Division, DVC, Maithon. The trend of sedimentation and its variation from the mean sedimentation have been analysed in the temporal context from 1955 to 2002 .

\section{Results and discussion}

\section{Spatial distribution of soil erosion factors in the Barakar River basin}

The spatial distribution of the soil loss through the RUSLE model has been derived using the map of rainfall erosivity (rain rate), soil types, slope and land use (Figs. 2, 3, 4). The area of potential soil erosion is susceptible to soil erosion or expected soil loss without the interference of human activities. The spatial distribution of the potential soil erosion has been derived using the map of rainfall erosivity (rain rate), soil types, and slope. Greater rainfall erosivity and high slope are highly vulnerable to water erosion. The soil type is also a major determinant of the erosional activity. The silty soils are highly susceptible to water and wind erosion while clayey type of soil is least susceptible to soil erosion (Brady and Weil 2012).

In the $\mathrm{R}$ factor map (Fig. 2a), the downstream regime and the southern portion of the Barakar basin have high 

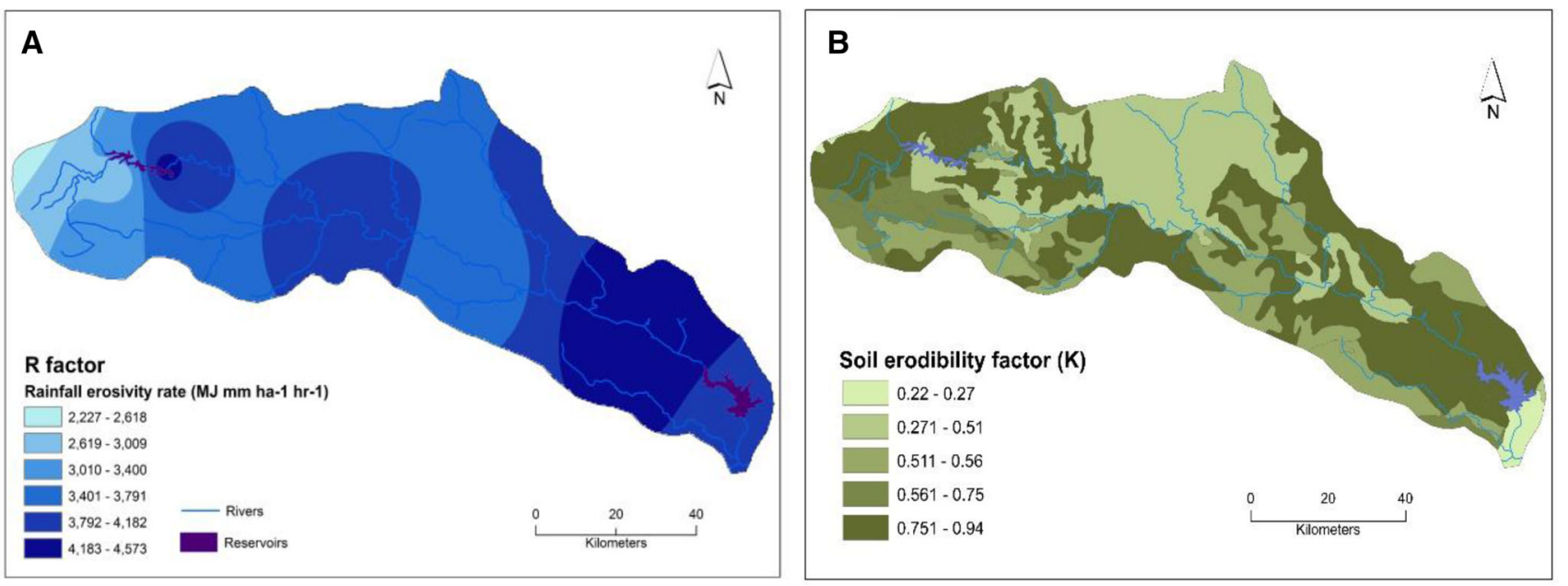

Fig. 2 Rainfall and soil factor map of the Barakar River basin for soil loss estimation. a Rainfall erosivity map and $\mathbf{b}$ K factor map
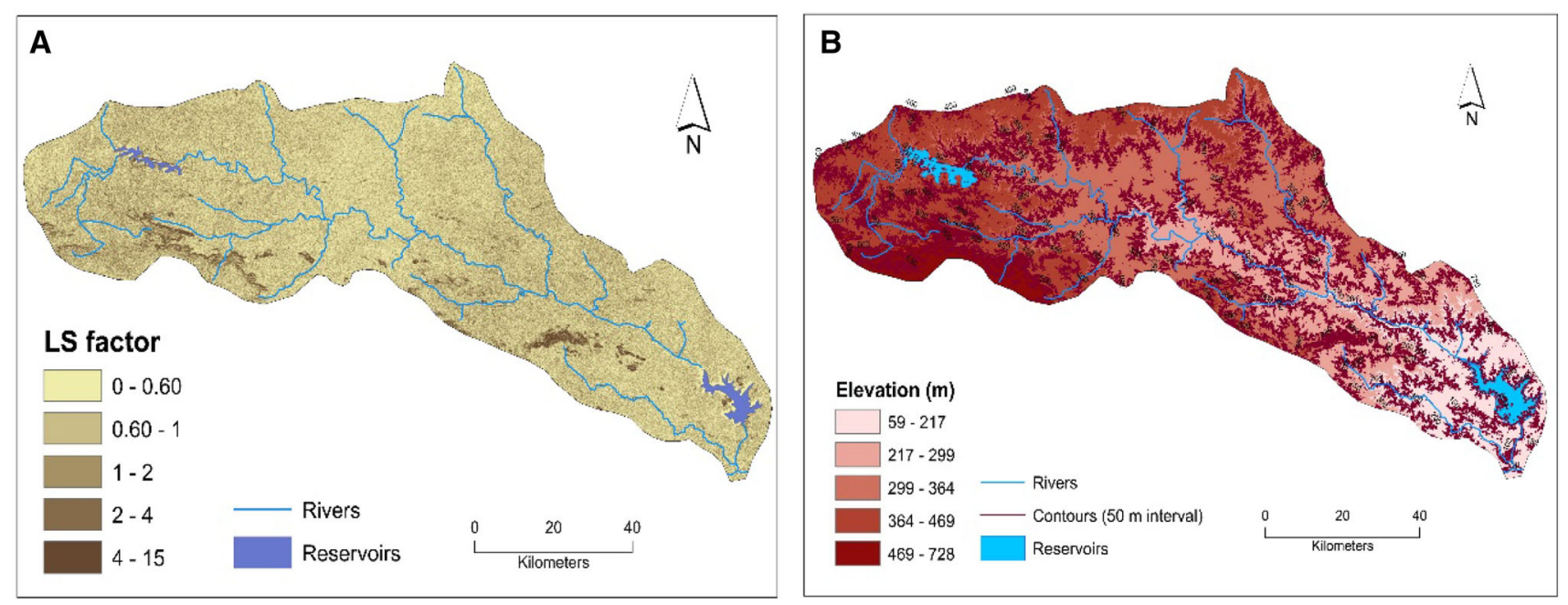

Fig. 3 Slope factor and elevation map for soil loss estimation of the Barakar River basin. a LS factor map and $\mathbf{b}$ elevation and contour map
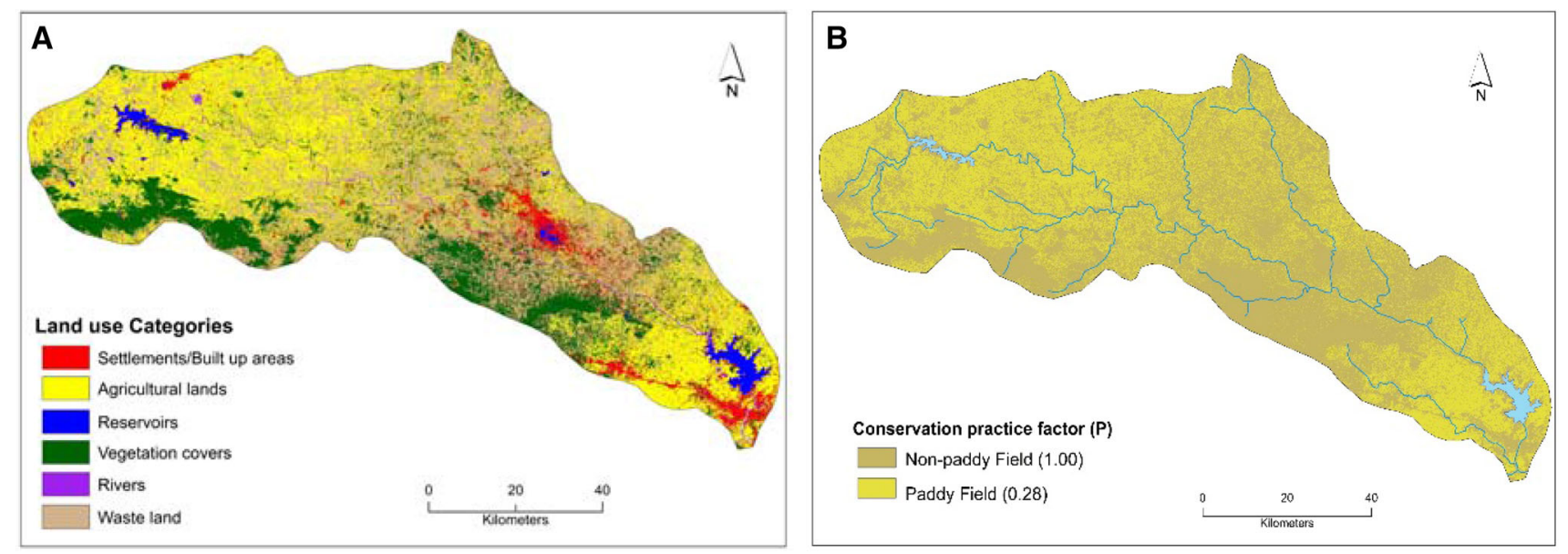

Fig. 4 Crop management and support practice factor of the Barakar River basin for soil loss estimation. a C factor map and $\mathbf{b}$ factor map 
erosivity as the precipitation rate is high in this regime. The downstream portion is the plateau fringe and plain area and is under the semi-humid climatic condition. High erosivity due to the high precipitation rate is associated with high susceptibility to erosion. On the contrary, the northern and western portion of the basin has been characterised by low erosivity.

In the $\mathrm{K}$ factor map of the basin, a higher value of 0.51 is more susceptible to erosion (Fig. 2b). Fine-loamy, coarse-loamy, fine and coarse-loamy texture having a higher value of $\mathrm{K}$ is more vulnerable to erosion. Soil with loose texture along with low organic matter is highly susceptible to erosion. Most of the areas of the Barakar river basin are covered with the Alfisol type of soil that is high in clay content with the presence of clay skin in the B horizon. This silicate clay has accumulated by the process of illuviation. The clay cover favours moderate leaching and infiltration process and is associated with high soil loss from the surface. The sandy Alfisol is susceptible to erosion by heavy rain if it is void of the natural surface litter (Brady and Weil 2012).

The LS factor map indicates that higher the value, greater its potentiality to erode. In the Barakar River basin, the elevation is ranged from $50 \mathrm{~m}$ (upstream section) to $700 \mathrm{~m}$ (downstream section) (Fig. 3b). Most of the area of the basin is characterised with the low slope or the low value of LS factor and it thus favours low to moderate soil loss in the basin. The distribution of the area of the LS factor is classified into six classes (Fig. 3a). It has been observed that about $90 \%$ of the basin area has values of less than two which indicates moderate erosion (Table 4). On the other hand, high vulnerable to erosion i.e. LS factor value of above five occupies the least area.

In the Barakar River basin, six categories (built-up areas/ settlements, vegetation covers, waste lands, agricultural lands, rivers, reservoirs) of the land use land cover are prominent. Agricultural land, built up areas/settlements and waste lands have the highest values as these contribute significantly to soil erosion (Fig. 4a). The built-up areas are limited to few areas, but the wastelands are scattered throughout the basin. The built-up areas may reduce erosion through concretisation, but it enhances erosion by disturbing the soil texture, organic matter, etc. In the western and the

Table 4 Area under different categories topographic factor (LS) of the Barakar River Basin

\begin{tabular}{lc}
\hline LS factor classes & Area $(\%)$ \\
\hline $0-0.5$ & 27.839 \\
$0.55-1$ & 39.013 \\
$1.01-1.56$ & 23.102 \\
$1.57-2.49$ & 7.882 \\
$2.50-4.29$ & 1.669 \\
$4.30-14.65$ & 0.493 \\
\hline
\end{tabular}

eastern side of the basin, agricultural lands are significant due to plain topography and low elevation. The vegetation cover in the hilly area, has the capability to protect the soil loss to a certain extent, but shallow to medium depth soil is more susceptible to erosion in the hilly areas. $\mathrm{P}$ factor depends on the erosion control practices that have been undertaken in the basin. In the Barakar basin, no significant measure has yet taken for the protection of the soil loss except for the agricultural activities which include mainly paddy and wheat cultivation (Fig. 4b). The hilly area has been characterised by the non-paddy field where high susceptibility of soil erosion is prominent.

\section{Estimation and spatial distribution of soil erosion in the Barakar River basin}

The distribution of soil loss in the Barakar River basin has been shown in Fig. 5b. The potential soil erosion map (Fig. 5a) and actual soil erosion map (Fig. 5b) has been generated from several RUSLE factor maps. Potential soil erosion map represents the expected erosion of the soil without the consideration of cover management and support practice factors. The potential soil loss is associated with the slope or the LS factor of the basin as the high vulnerability of potential soil loss is observed in the high slope areas (Fig. 5a). The actual soil loss is associated with the addition of cover management and the support practice factors. The estimated soil erosion of the Barakar river basin is ranged from 0 to $282 \mathrm{t} \mathrm{ha}^{-1}$ year $^{-1}$ (Fig. 5b) and it is considered as moderate to high soil loss as mentioned by Pandey et al. (2007). The soil loss of the basin has been categorised into six categories. In Table 5, it is observed that the major part (about $80 \%$ ) of the river basin has experienced a low soil erosion of less than $14 \mathrm{t} \mathrm{ha}^{-1}$ year and it signifies that the support practices are important in this region where the paddy cultivation is dominant. On the contrary, soil loss of more than $100 \mathrm{t} \mathrm{ha}^{-1}$ year $^{-1}$ is significant in $0.08 \%$ of the river basin. The critically high soil erosion in this region is associated with the plateau fringe areas and the support practices are not significant as this areas are devoid of any type of cultivation. The area of soil loss is inversely related to the amount of soil loss and it is the indication of the high amount of soil loss that is observed in few areas of the catchment and vice versa (Fig. 6). Overall, in the basin, the soil loss is high in the headwater or upstream section of the Barakar river, where shallow depth of the Alfisol soil promotes erosion. In the downstream regime of the river, the high soil loss is the result of the built up areas and high rainfall erosivity. In these areas, poor agricultural practices also promote soil loss. The high percentage of waste lands in the plateau and plateau fringe area, the presence of Alfisol soil and high rainfall erosivity in the downstream section favour 

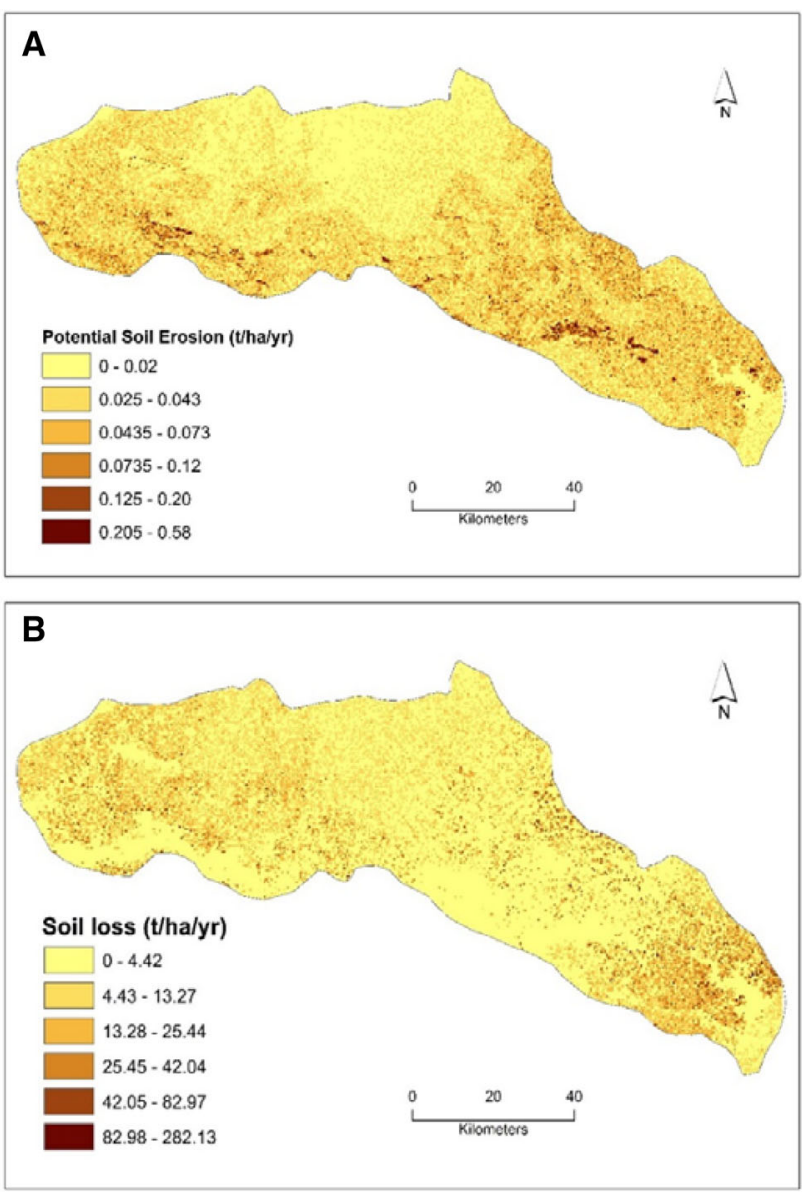

Fig. 5 Soil erosion map of the Barakar River basin. a Potential soil erosion map and $\mathbf{b}$ actual soil loss map

Table 5 Area under different categories of soil loss of the Barakar River Basin

\begin{tabular}{lc}
\hline Soil loss classes $\left(\mathrm{t} \mathrm{ha}^{-1} \mathrm{year}^{-1}\right)$ & Area $(\%)$ \\
\hline $0-0.42$ & 62.852 \\
$0.43-13.27$ & 19.027 \\
$13.28-25.44$ & 12.347 \\
$25.45-42.04$ & 4.609 \\
$42.05-82.97$ & 1.084 \\
$82.98-282.13$ & 0.077 \\
\hline
\end{tabular}

moderate to high amount of soil loss in the river basin. Except for the major cities (Dhanbad, Barakar, Giridih, Koderma) and its surrounding areas, the population density is not too high and the vegetation covers can protect the soil loss from the plateau areas as Jharkhand state is known as the 'Land of forests'. Though waste lands have occupied significantly in the middle portion of the basin, actual soil erosion is low in the region. Low slope, land use land cover character and support practice factors can cope up with erosion in this region.

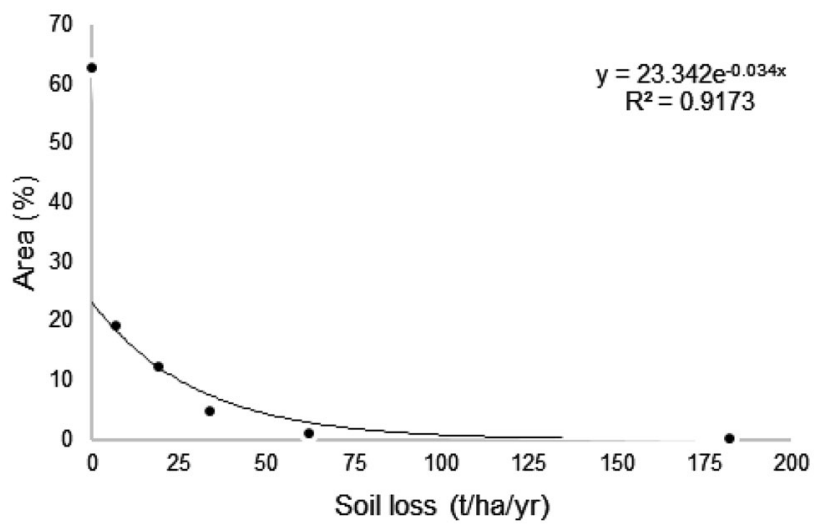

Fig. 6 Relationship between amount of soil loss and area soil loss of the Barakar River basin

\section{Drainage density and soil erosion of the Barakar river basin}

The drainage density (Dd) of a cathment area depends on the precipitation, infiltration capacity, underlying rock and soil texture, vegetation, hydraulic conductivity of the underlying soil (Sreedevi et al. 2009). The high Dd of the river basin is characterised by high elevation and slope (Fig. 7a). The western portion of the basin or the upstream regime and eastern portion of the downstream regime of the Barakar river is charecterised by high Dd. Soil erosion of the Barakar river basin is partly related to the drainage density. The overlying map of drainage density and soil loss reveals that the in the upstream section of the basin, Dd and soil loss are high to very high (Fig. 7b). It is associated with high elevation with the presence of several finger tip streams and the shallow depth of the Alfisol soil. Thus, the loose coarse soil and a number of streams promote soil loss in this area. In the eastern portion of the basin or the downstream reach of the river is associated with the high soil loss but the Dd is not so high. In this reach, $\mathrm{C}$ factor and $\mathrm{R}$ factor is the reason for high soil loss. At the mouth of the river (Fig. 1), the high Dd is not related to high soil loss as the elevation and slope of this region is low.

\section{Role of soil erosion in reservoir sedimentation of Maithon reservoir dam}

Soil erosion of the catchment areas is the source of deposition in the riverbed and the reservoir of the river. Reservoir sedimentation is also influenced by soil erosion in the upper catchment of the reservoir. In the Barakar River, two significant reservoirs are Tilaiya dam reservoir and Maithon dam reservoir. Sedimentation in the river and reservoir has increased with the increase in soil loss. The increase of the braid-channel ratio in the downstream 

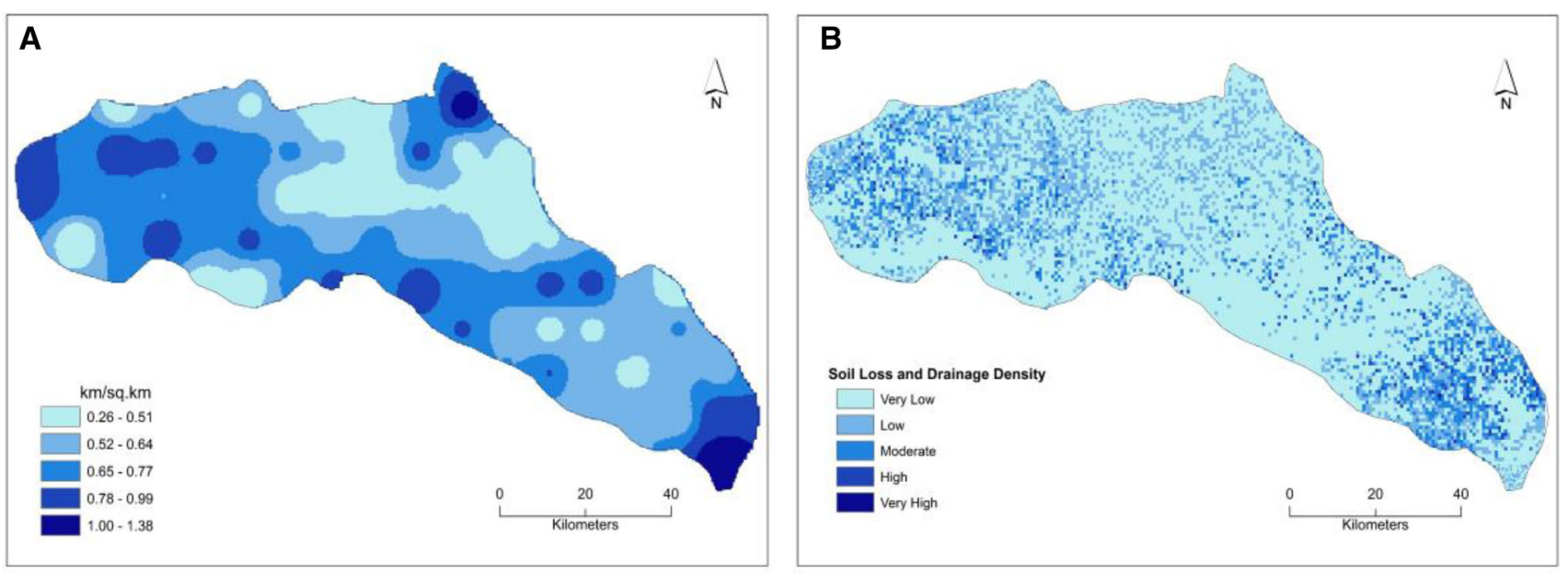

Fig. 7 Role of drainage density in soil loss of the Barakar river basin, a Drainage density map and b overlay of drainage density and soil loss map

regime of the river is also a result of the soil loss in the upper catchment areas (Biswas 2014) and greater discharge of sands (Khan 1987). The same scenario has been observed at the Maithon dam reservoir, where there is an increase in the tendency of the sediment deposition rate and fluctuation from the mean of sediment deposition from 1955 to 2002 (Fig. 8). In the spatial context of the reservoir, the thickness of sediment deposition gradually decreases upward to the dam (Fig. 8). The sediment deposition rate from 1955 to 2002 is $1306 \mathrm{~m}^{3} / \mathrm{km}^{2}$ year $^{-1}$. The high sedimentation in the Maithon reservoir may be due to a large amount of soil loss at the upstream part of the river basin. In the lower section of the river, the rills and gully development are significant except at the bank that is made up of sandstone rocks (Biswas 2014). As a result of soil loss in the upper catchment areas, the reservoir capacity has been depleted in dead storage as well as in live storage space. From 1955 to 2002, the total volume of capacity loss is $327 \times 10^{6} \mathrm{~m}^{3}$ and average annual loss of capacity is $7.02 \times 10^{6} \mathrm{~m}^{3}$. In the reservoir, all the zones (dead storage, flood zone, live storage) are characterised by the loss of capacity due to sedimentation. From 1995 to 2002 , the reduced amount of dead storage, live storage and flood zones are 113.3, 165.78 and $48.27^{1} \mathrm{Mm}^{3}$ respectively. The soil loss in the catchment area not only affects the reach wise distribution of the sediment deposition but also affects the depthwise distribution of the sedimentation. In the depthwise distribution of sediment, it has been found from the literature that $65 \%$ of the total sediment deposition takes place in the top $47 \%$ of the reservoir, and it is an indication of upstream deposition. Whereas, the Maithon reservoirs favours slight upstream deposition

\footnotetext{
${ }^{1} \mathrm{Mm}^{3}$ represents million $\mathrm{m}^{3}$
}

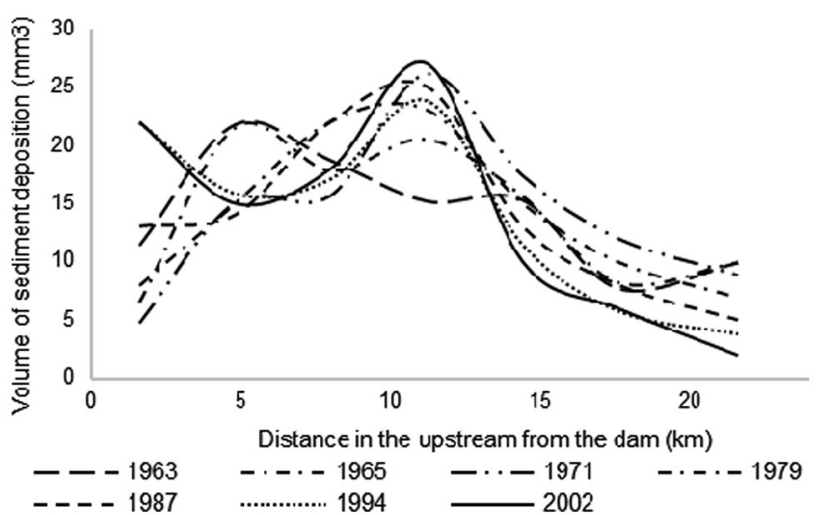

Fig. 8 Temporal changes of sediment deposition in upstream distance from the Maithon dam (1963-2002)

(Damodar Valley Corporation 2003; Central Water Commission 1998).

\section{Changes in the rate reservoirs sedimentation of the Barakar River}

The reservoir sedimentation is the combined effect of soil erosion and land use changes in the catchment area and other human activities in the river and its basin (Biswas 2014). The rate of sediment deposition had declined in the initiation phase of the Maithon dam construction in 1957 (Fig. 9a). However, post 1965, there has been an increase in the sediment deposition rate since 1970. In between 1963 and 1979, the sediment deposition was less than the mean of the whole period. After 1980, an increase in the trend of deposition has been observed as the effects of an increase in the suspended and bed load sediment of the channel that accelerate the sedimentation process. The volume of deposition from the mean deposition has also 


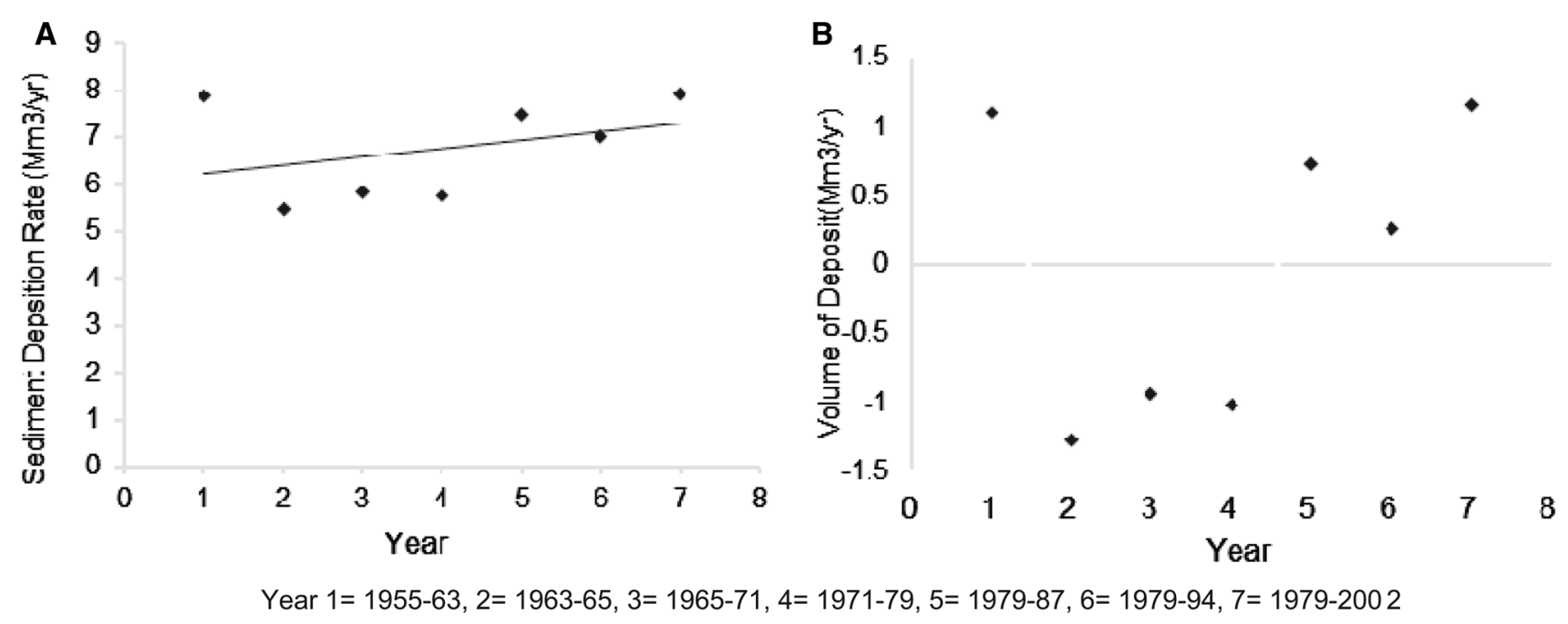

Fig. 9 Temporal changes of sediment deposition at Maithon reservoir (1955-2002). a Increase of sediment deposition rate and b volume of deposition (right) at the reservoir

been increased after 1980's at the Maithon reservoir (Fig. 9b). Before 1980's, the volume of sedimentation is below from mean deposition. The increasing trend in reservoir sedimentation and volume of deposition is caused by the removal of forests or reduction in vegetation covers in the river basin. Thus, the reduction of forest leads to soil erosion and land degradation in the catchment areas and increase in braid characters in the river bed along with an increase in the suspended and bed load materials of both the river and the reservoir (Ward et al. 2009).

\section{Conclusion}

The estimation and spatial distribution of soil erosion in the Barakar river basin using the pre-existing method of RUSLE and GIS technique, consider that the basin has faced moderate to high soil loss. Most of the areas $(\sim 80 \%)$ have suffered soil loss of less than $14 \mathrm{t} \mathrm{ha}^{-1}$ year $^{-1}$. A significant negative relationship $\left(\mathrm{R}^{2}=0.92\right)$ exists between the area of soil loss and the amount of soil loss, which depicts the high amount of soil loss in a few areas and vice versa. The fallow lands are highly susceptible to erosion. The limitation in the absence of sediment yield data forces to exclude the measurement of sediment delivery ratio. Then, the amount of reservoir sedimentation rate might have been accurately measured. Hence, no field data had been collected, and thus no calibration/verification/validation could be undertaken. Validation of the soil loss might have resulted more authentic and reliable. Hence, the remote sensing and GIS tools play a significant role in the generation of required maps for the RUSLE model. GIS analyses the input details in a much faster along with the better spatial distribution of output maps that are legible to a layman also. Use of GIS techniques to measure the soil loss can be more authenticate and reliable with high-resolution spatial data.

The land use changes increase the soil loss in the plateau and plateau fringe areas. It is hardly possible to stop the soil loss from the earth surface, but, it could be reduced through the proper land use and support practices. Crop rotation, contour strip- cropping play a significant role in controlling soil loss and overgrazing should be prohibited to reduce the surface soil loss. The conservationists and planners should implement the management strategies more accurately for the catchment areas to sustain the environment and accelerate the longevity of the reservoirs.

Acknowledgments The authors gratefully acknowledge the anonymous reviewers for their valuable comments, suggestions and assistance in the improvement of the paper. The corresponding author would like to thank Aditi Gain (Assistant Professor, T. D. B. College, Raniganj, West Bengal) for her help in proof reading.

\section{References}

Arnold JG, Fohrer N (2005) SWAT 2000: current capabilities and research opportunities in applied watershed modelling. Hydrol Process 19:563-572

Balasubramani K, Veena M, Kumaraswamy K, Saravanabavan V (2015) Estimation of soil erosion in a semi-arid watershed of Tamil Nadu (India) using revised universal soil loss equation (rusle) model through GIS. Model Earth Syst Environ 1(3):1-17

Beskow S, Mello CR, Norton LD, Cur N, Viola MN, Avanzi JC (2009) Soil erosion prediction in the Grande River Basin, Brazil using distributed modeling. Catena 79:49-59

Bhattarai R, Duttta D (2007) Estimation of soil erosion and sediment yield using GIS at catchment scale. Water Resour Manage 21(10):1635-1647 
Biswas SS (2014) Role of Human induced factors, soil erosion and climatic variability in changing the fluvial system: a case study of the Barakar River Basin, India. Unpublished M. Phil. Dissertation, Jawaharlal Nehru University, New Delhi

Brady NC, Weil RC (2012) The nature and properties of soils. Pearson education, New Delhi

Central Water Commission (1998) Capacity survey of Tilaiya reservoir. RITES, New Delhi

Damodar Valley Corporation (2003) Report on sedimentation survey on Maithon reservoirs. Hydraulic Data Division, DVC, Maithon

Das G (2012) Hydrology and soil conservation engineering including watershed management. 2nd edn. PHI Learning Pvt. Ltd, New Delhi

De Roo AP, Wesseling CG, Ritsema CG (1996) LISEM: a single event physically-based hydrologic and soil erosion model for drainage basins: I. Theory, input and output. Hydrol Process 10(8):1107-1117

Flanagan DC, Gilley GE, Franti TG (2007) Water Erosion Prediction Project (WEPP): development history, model capabilities, and future enhancements. Trans ASABE 50:1603-1612

Ghosh S, Guchhait SK (2012) Soil loss estimation through USLE and MMF methods in the lateritic tracts of Eastern Plateau Fringe of Rajmahal Traps. Ethiop J Environ Stud Manag 5(529-541):4

Hardon CP (1993) Land use, soil erosion, and Reservoir sedimentation in an Andean Drainage Basin in Ecuador. Mt Res Dev 13:177-184

Horton RE (1945) Erosional development of streams and their drainage density: hydrophysical approach to quantitative geomorphology. Geol Soc Am Bull 56:275-370

ICAR (2008) Assessment and mapping of some important soil parameters including soil acidity for the state of Jharkhand (1:50,000 scale) towards rational land use plan, Sponsored by: Department of Agriculture \& Cane Development, Govt. of Jharkhand: National Bureau of Soil Survey and Land Use Planning (ICAR) Regional Centre, Kolkata and in collaboration with: Dept. of Soil Science \& Agricultural Chemistry, BAU, Ranchi, Jharkhand

Jain MK (1996-1997) Estimation of soil erosion and sediment yield using GIS. National Institute oh Hydrology, Jal Vigyan Bhawan, Roorkee

Jain MK, Kothyari UG (2000) Estimation of soil erosion and sediment yield using GIS. Hydrol Sci J 45(5):771-786

Jain SK, Kumar S, Varghese J (2001) Estimation of soil erosion for a Himalayan watershed using GIS technique. Water Resour Manag $15: 41-54$

Jiang L, Yao Z, Lui Z, Wu S, Wang R, Wang L (2015) Estimation of soil erosion in some sections of Lower Jinsha River based on RUSLE. Nat Hazards 76:1831-1847

Joshi VU, Nagare V (2009) Land use change detection along the Pravara River Basin in Maharashtra, using Remote Sensing and GIS Techniques. AGD Landsc Environ 3:71-86

Khan ZA (1987) Paleodrainage and paleochannel morphology of a Barakar river (Early Permian) in the Rajmahal Gondwana basin, Bihar, India. Palaeogeogr Palaeoclimatol Palaeoecol 58:235-247

Lim KJ, Sagong M, Engel BA, Tang Z, Choi J, Kim KS (2005) GISbased sediment assessment tool. Catena 64:61-80

McCool DK, Brown LC, Foster GR, Mutchler CK, Mayer LD (1987) Revised slope steepness factor for the Universal Soil Loss Equation. Trans ASAE 30:1387-1396

Meusburger K, Konz N, Schaub M, Alewell C (2010) Soil erosion modelled with USLE and PESERA using QuickBird derived vegetation parameters in an alpine catchment. Int J Appl Earth Obs Geoinf 12:208-215

Millward AA, Mersey JE (1999) Adapting the RUSLE to model soil erosion potential in a mountainous tropical watershed. Catena 38(2):109-129
Misra K (1999) Watershed management activities in Damodar Valley Corporation at a glance. Soil Conservation Department, Damodar Valley Corporation, Hazaribagh

Morgan RPC, Morgan DDV, Finney HJ (1984) A predictive model for the assessment of soil erosion risk. J Agric Eng Res 30:245-253

Morgan RP, Quinton JN, Smith RE, Govers G, Poesen JW, Auerswald K, Styczen ME (1998) The European soil erosion model (EUROSEM): a process-based approach for predicting sediment transport from fields and small catchments. Earth Surf Process Landf 23:527-544

Musgrave GW (1947) The quantitative evaluation of factors in water erosion-a first approximation. J Soil Water Conserv 2(3):133-138

Narayan DV, Babu R (1983) Estimation of soil erosion in India. J Irrig Drain Eng 109(4):419-431

Pandey A, Chowdary VM, Mal BC (2007) Identification of critical erosion prone areas in the small agricultural watershed using USLE, GIS and remote sensing. Water Resour Manag 21:729-746

Pandey A, Chowdary VM, Mal BC, Billib M (2008) Runoff and sediment yield modeling from a small agricultural watershed in India using the WEPP model. J Hydrol 348(3-4):305-319

Pérez-Rodríguez R, Marques MJ, Bienes R (2007) Spatial variability of the soil erodibility parameters and their relation with the soil map at subgroup level. Sci Total Environ 378:166-173

Prasannakumar V, Vijith H, Abinod S, Geetha N (2012) Estimation of soil erosion risk within a small mountainous sub- watershed in Kerala, India, using Revised Universal Soil Loss Equation (RUSLE) and geo-information technology. Geosci Front 3(2):209-215

Rahman MR, Shi ZH, Chongfa C (2009) Soil erosion hazard evaluation-an integrated use of remote sensing, GIS and statistical approaches with biophysical parameters towards management strategies. Ecol Model 220(13):1724-1734

Rao YP (1981) Evaluation of cropping management factor in Universal Soil Loss Equation under natural rainfall condition of Kharagpur, India. In: Proceedings of the South-east Asian Regional Symposium on Problems of Soil Erosion and Sedimentation, Bangkok, vol 27-29, pp 241-254

Renard KG, Freimund JR (1994) Using monthly precipitation data to estimate the R factor in the revised USLE. J Hydrol 157:287-306

Renard KG, Foster GR, Weesies GA, Porter JP (1991) RUSLE, Revised Universal Soil Loss Equation. J Soil Water Conserv 46(1):30-33

Sen PK, Prasad N (2002) An introduction to the geomorphology of India. Allied Publishers Pvt. Ltd, New Delhi

Singh RL (1971) India: a regional geography. National geographical Society of India, Varanasi

Sinha D, Joshi V (2012) Application of Universal Soil Loss Equation (USLE) to Recently Reclaimed Badlands along the Adula and Mahalungi Rivers, Pravara Basin, Maharashtra. J Geol Soc India 80:341-350

Sreedevi PD, Owais S, Khan HH, Ahmed S (2009) Morphometric analysis of a watershed of South India using SRTM data and GIS. J Geol Soc India 73(4):543-552

Strahler AN (1964) Quantitative geomorphology of drainage basins and channel networks. In: Chow VT (ed) Handbook of applied hydrology. McGraw-Hill, New York, pp 439-476

Ward PJ, van Balen RT, Verstraeten G, Renssen H, Vandenberghe J (2009) The impact of land use and climate change on late Holocene and future suspended sediment yield. Geomorphology 103(3):389-400

Williams JR (1975) Sediment routing for agricultural watersheds. Water Res Bull 11:965-974 
Wischmeier WH, Smith DD (1965) Predicting rainfall erosion losses from Cropland East of the Rocky Mountains. Handbook no. 282, United States Department of Agriculture, Washington DC

Yang D, Kanae S, Oki T, Koikel T, Musiake K (2003) Global potential soil erosion with reference to land use and climate changes. Hydrol Process 17(14):2913-2928
Yoder DC, Foster GR, Weesies GA, Renard KG, McCool DK, Lown JB (2004) Evaluation of the RUSLE Soil Erosion Model. In: Thomas DL, Huffman RL (eds) Agricultural non-point water quality models: Their use and application. University of Tennessee Agricultural Experiment Station: Southern Cooperative Series Bulletin, pp 107-116 